\title{
Measuring Overeducation: Incidence, Correlation and Overlaps Across Indicators and Countries
}

\author{
Queralt Capsada-Munsech $^{1}$ (D)
}

Accepted: 25 March 2019 / Published online: 28 March 2019

(c) The Author(s) 2019

\begin{abstract}
The methodological debate on how to measure overeducation has been present since the introduction of the topic in the academic debate. Nevertheless, there is still no consensus on a preferred indicator. This article aims at contributing to the existing methodological debate providing systematic and cross-country evidence on the variation across overeducation measurements. Using REFLEX/HEGESCO and EULFS datasets, I provide evidence on within and across countries variation on the incidence, correlation and overlaps across the main types of objective, statistical and subjective overeducation indicators. Results suggest that worker's self-reported indicators better cope with comparative studies, while in single-country studies objective indicators are likely to provide a more in-depth and detailed measurement. The use of statistical indicators is advised in contexts with labour markets that easily adapt to educational and employment changes, especially if these are not affected by credential inflation. However, it is advisable to use more than one indicator whenever data allows it, as different types of overeducation measurements provide different outcomes and results are likely to be complementary rather than excluding information on the overeducation phenomenon. This is especially relevant when overeducation is used as a dependent variable rather than a predictor. An initial review and discussion of the existing types of overeducation measurements and their advantages and drawbacks precedes the empirical evidence.
\end{abstract}

Keywords Overeducation · Educational mismatch · University graduates · Measurement · Europe

\section{Introduction}

Recent higher education expansion among OECD countries has triggered a thriving debate on credentialism and overeducation (Kucel 2011; Quintini 2011; Schofer and Meyer 2005). The estimated incidence of overeducation associated with higher education expansion is around $26 \%$ in the U.S. and $22 \%$ in European countries (Groot and van den Brink 2000). Over the past few decades, European countries have experienced

Queralt Capsada-Munsech

queralt.capsada-munsech@durham.ac.uk

1 Durham University, 32 Old Elvet, Durham DH1 3HN, UK 
overeducation to a different extent: while the average overeducation incidence among graduates is around 26\%, it ranges from 14\% in Portugal to $45 \%$ in Spain (Verhaest and van der Velden 2013). Convergence in overeducation trends are taking place, with rates becoming static or even falling in most European countries (McGuinness et al. 2018).

However, these figures are not consistent across all empirical studies. Since Freeman's seminal work The Overeducated American (Freeman 1976) one of the main questions around the overeducation phenomenon has been how to measure it. The methodological debate started during the 1980s and it is still ongoing (Battu et al. 2000; Chevalier 2003; Groot and van den Brink 2000; Halaby 1994; Hartog 2000; Kucel 2011; McGuinness 2006; Quintini 2011; Verhaest and Omey 2006). While in the initial years the discussion was based on the suggestion of new overeducation indicators from an objective (Eckaus 1964), statistical (Clogg and Shockey 1984; Verdugo and Verdugo 1989) and subjective approach (Duncan and Hoffman 1981), later on the discussion moved to addressing the biases, advantages and drawbacks of each measurement type. For the past years more refined measurements have been proposed thanks to new data sources and methodologies, allowing for the comparison of overeducation with similar concepts, such as overskilling (Flisi et al. 2017). However, there is still no consensus on which is the best indicator to measure overeducation or other types of occupational mismatches. Measurement is usually driven by data availability and it is advised to use more than one indicator to cope with the limitations of each type of measurement.

Nevertheless, there are substantial differences in overeducation figures across measurements and the use of different overeducation indicators sometimes leads to different outcomes (Verhaest and Omey 2006, 2010). The degree of correlation among measurements tends to be limited-usually below 0.5-suggesting short overlaps among the individuals identified as overeducated across measurements (McGuinness 2006). This has not traditionally been a great matter of concern, as most of the economic literature on overeducation has focused on wage returns to overeducation, which remain quite similar regardless of the measurement used. However, more recent studies focusing on overeducation as a phenomenon itself and using it as a dependent variable are showing cross-measurement differences as a matter for discussion. The importance to identify who these individuals are and what characterises them becomes a crucial topic. Additionally, cross-country comparisons are also suggesting a wide variation on overeducation figures across and within countries depending on the overeducation indicator employed.

Therefore, this article aims at systematically explore and provide evidence on the differences in overeducation measurement with regards to their incidence, correlation and overlap across European countries in order to shed some light on the appropriateness to use overeducation indicators depending on the focus and scope of the research (e.g. single case study vs country comparison). The remaining of the paper is structured as follows: the first section presents the indicators traditionally used to measure overeducation and discusses their advantages and drawbacks, as well as their potential correlations and overlaps from a comparative perspective. Second, the data and methods to present empirical evidence for a range of overeducation indicators are outlined. Third, the results of the comparison of different indicators are presented and discussed. Finally, the conclusions point out at the main topics to bear in mind when selecting and using overeducation indicators as dependent variables. 


\section{Measuring Overeducation}

The literature on overeducation has heavily relied on qualifications as a proxy to measure individuals' knowledge and skills. However, this implies making some strong assumptions which are worth pointing out. Considering qualifications as a good measure to calculate overeducation assumes that relevant knowledge and skills for jobs are only acquired via formal education (Halaby 1994), omitting skills gained in other life domains, such as onthe-job training and family socialisation. Another strong assumption derived from using qualifications as an overeducation measure is that no skills heterogeneity is expected across individuals (Verhaest and Omey 2006). Individuals with college degrees from different fields of study are considered to have the same skills level, even if one studied medicine and the other one law.

Nevertheless, because of limited data availability, credentials have been used for the past three decades of academic research as a valid measure to identify overeducated workers, although some initial efforts were directed to analyse overeducated workers by skills endowment. Using data for British graduates, Chevalier (2003) differentiated between 'apparently overeducated' (i.e. their educational qualifications exceed that of the job, but their skills are similar to those of their adequately matched co-workers) and 'genuinely overeducated' (i.e. their skills are underutilised at work). Given the limitations of relying only on formal qualifications, more recent surveys and data projects have paid more attention to skills measurement, focusing on skills and knowledge used at work (e.g. PIAAC, REFLEX/HEGESCO). Although still far from perfect, these new datasets have encouraged and facilitated the replication of previous analyses adding to formal qualifications skills used and/or gained at work or in other life domains, pushing the debate to skills mismatch concerns and its relationship with educational mismatch (Flisi et al. 2017; Mateos Romero et al. 2017).

Beyond the advances in the measurement and discussion of overskilling, the measurement of overeducation still remains under debate, given the wide spectrum of possible forms of measurement. Building up on the classifications proposed in previous literature reviews on overeducation (Kucel 2011; Quintini 2011; Verhaest and Omey 2006), the most commonly used overeducation measures can be classified into three groups: (1) Job Analysis, (2) Realized Matches, and (3) Workers' self-Assessment, presented and discussed as follows. While the first two types of measurement are usually referred to as objective indicators, the third ones is commonly known as the subjective approach. However, within each group of measurements there are variations, which are discussed below and summarised in Fig. 1.

1. Job Analysis (JA) presents an objective measure of overeducation, introduced by Eckaus (1964) and commonly used by pioneer overeducation studies (Burris 1983; Rumberger 1981; Scoville 1966). It is a normative approach based on a priori assumed correspondence between education and occupations, constructed on the criteria of job experts assessing educational requirements of occupations. Therefore, a worker is considered to be overeducated when her/his educational level exceeds the one assigned to be necessary to perform a job, according to job experts' classification. The most well-known classification is the American Dictionary of Occupational Titles (DOT), recently replaced by the Occupational Information Network $\left(\mathrm{O}^{*} \mathrm{NET}\right)$ online database. DOT used to be constructed by job analysts who were visiting worksites and gathering information on the tasks involved in the job. Nowadays, the O*NET is constantly updated by survey- 


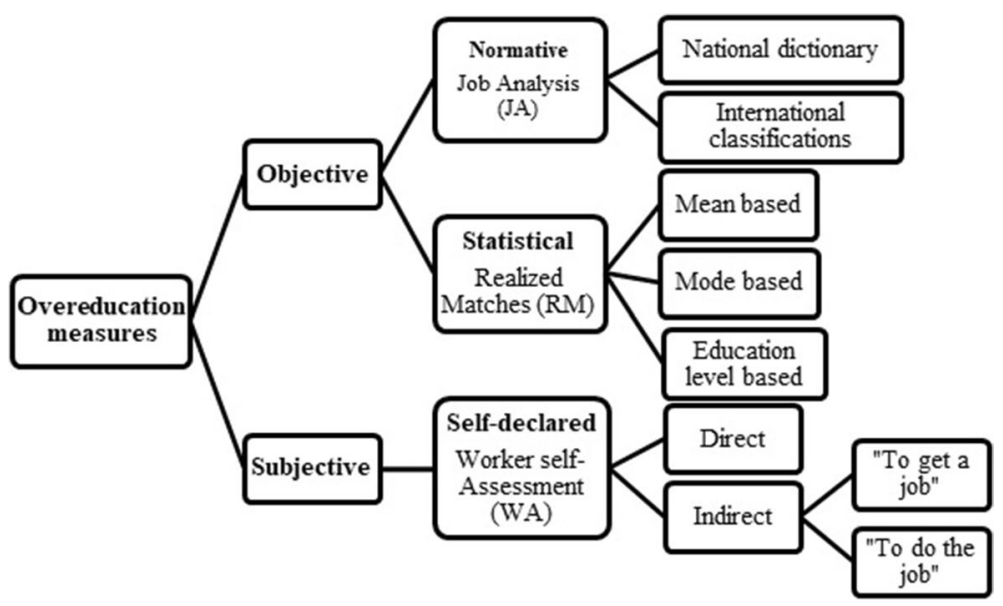

Fig. 1 Classification of overeducation measurements. Source: Author's elaboration, based on Halaby (1994), Hartog (2000), Kucel (2011), McGuinness (2006), Quintini (2011) and Verhaest and Omey (2006)

ing a broad range of workers from different occupations. Other national occupational dictionaries worth mentioning are the Standard Occupation Classification (SOC) system developed in the United Kingdom, the Canadian National Occupation Classification (NOC) and the Australian and New Zealand Standard Classification of Occupations (ANZSCO). For international comparisons, a standardised way to execute this measurement is comparing the UNESCO's International Standard Classification of Education ${ }^{1}$ (ISCED) level with the International Labour Organisation's (ILO) International Standard Classification of Occupations ${ }^{2}$ (ISCO) level.

2. Realized Matches (RM) is another type of objective indicator used in the overeducation literature. It was first proposed by Clogg and Shockey (1984), developed by Verdugo and Verdugo (1989) and later used by other scholars (Bauer 2002; Groot and van den Brink 1997). This statistical approach classifies as overeducated those who exceed the mean years of education for their occupation by more than one standard deviation above the mean in relation to the rest of workers in the occupation. The main assumption of this indicator is that in each occupation there is a core of matched workers, and overeducated workers are considered in relation to this benchmark. Statistical bias is expected because of the assumed symmetry of this indicator between under and overeducation. In order to avoid this bias some authors have used the median or mode as a less sensitive statistic to outliers (Mendes de Oliveira et al. 2000), while others have argued that the achieved level of education is a more reliable measure instead of years of education, suggesting that individuals should be considered as overeducated when exceeding the educational level of $80 \%$ of the workers in their occupation (Ortiz and Kucel 2008). As employers

\footnotetext{
1 ISCED 2011 revision: ISCED 0-2 corresponds to lower secondary education levels or below; ISCED 3-4 to upper secondary education level; ISCED 5-8 to tertiary education levels, from short-cycle of tertiary education (ISCED 5) to doctoral level (ISCED 8) (UNESCO 2011).

2 ISCO 2008: ISCO 1 Managers; ISCO 2 Professionals; ISCO 3 Technicians and Associate Professionals; ISCO 4 Clerical Support Workers; ISCO 5 Services and Sales Workers; ISCO 6 Skilled Agricultural, Forestry and Fishery Workers; ISCO 7 Craft and Related Trades Workers; ISCO 8 Plant and Machine Operators and Assemblers; ISCO 9 Elementary Occupations (International Labour Organisation 2008).
} 
use qualifications as a proxy of skills rather than years of education, the latter seems a more contemporaneous measure of overeducation.

3. Worker self-Assessment (WA) is a subjective measurement of overeducation first proposed by Duncan and Hoffman (1981) and later used by many more (Battu et al. 2000; Sicherman 1991; Sloane et al. 1999; Verhaest and Omey 2010). Measuring overeducation from a self-reported approach consists in using individual's opinion on whether the job requirements matches her/his educational level and/or skills (Halaby 1994). It can be directly asked to workers if they think they are overeducated, or it can be addressed indirectly, asking workers about the required education to actually do the job or to get the job and comparing it to workers' educational level (Verhaest and Omey 2006). The fact of asking for the normative ( $d o$ ) or practical ( $g e t)$ approach can tackle different conceptions of overeducation - namely Human Capital Theory and credential inflation-as reported in some empirical studies (Dolton and Silles 2008). Although this indicator has traditionally been treated as a dummy variable, some authors have recently proposed an ordinal approach based on increasing degrees of overeducation in order to deal with vertical differentiation in higher education brought by Masters and other postgraduate qualifications (Barone and Ortiz 2011).

\section{Advantages and Disadvantages of Each Measurement}

Each one of these different approaches to measuring overeducation has its own advantages and drawbacks, summarised in Table 1 below. Starting with the JA approach to overeducation, from a conceptual perspective it has been argued that JA indicators are the most rigorous and accurate ones, as they consider the requirements to get and do the job, and this is why they have been usually considered as normatively superior (Halaby 1994). Nevertheless, one of the barriers to use JA indicators is that they are costly to construct, difficult to keep up-to-date, they can easily become obsolete with occupational change and they are heavily affected by credential inflation (Barone and Ortiz 2011). These are the main reasons why this kind of indicator is not available in numerous countries. On top of that, they are usually nationally targeted and do not allow for cross-country comparisons. Another limitation is that their rigidity does not take into account the diversity of jobs inside occupational categories, assuming that all jobs in an occupation require the same skills and knowledge (Halaby 1994). For instance, among the occupational level of Managers (ISCO 1) the skills and knowledge required varies widely from one job to another and by sector. It could even be questioned if a tertiary degree is required to successfully perform as a manager, especially in labour markets where small and medium enterprises (SMEs) are the norm. Among Professionals (ISCO 2) there might be a wider agreement that university graduates have the adequate skills and knowledge to perform the range of jobs included. However, among Technicians and Associate Professionals (ISCO 3) the variety of jobs increases, as well as their qualification requirements. Thus, matching broad occupational groups to educational levels might lead to systematic biases which are also likely to vary across countries, making it more difficult to use for cross-country comparison.

RM indicators are good to explore an individual's relative position to the rest of the workers in an occupation/job. This type of indicator easily adapts to skills upgrading due to technological change or new formal qualification requirements, what might ease comparisons across cohorts, time points or countries that easily adapt to new skills requirements. Another advantage of RM indicators is that it can be calculated using standard indicators of 


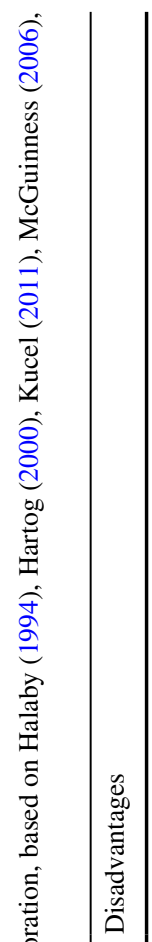

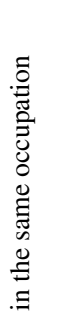

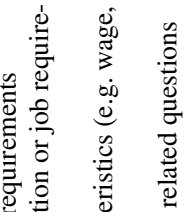

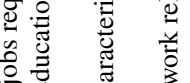

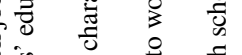

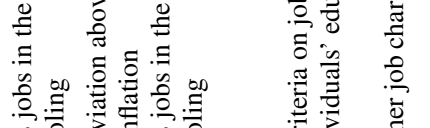

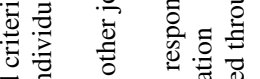

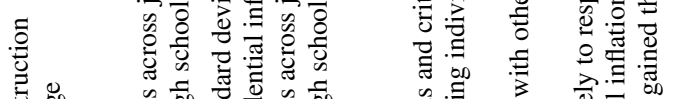

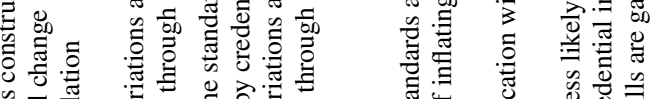

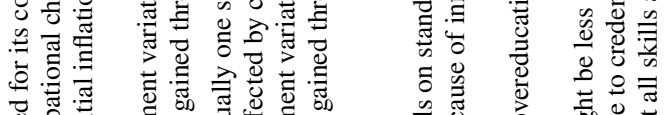

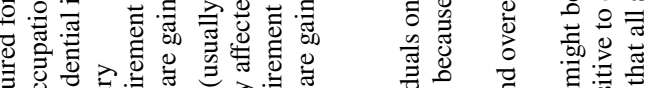

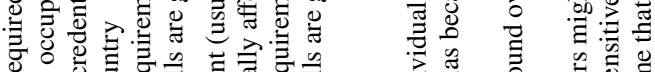

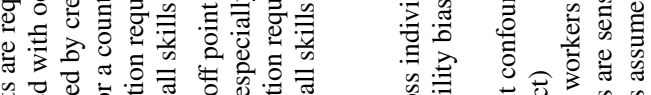

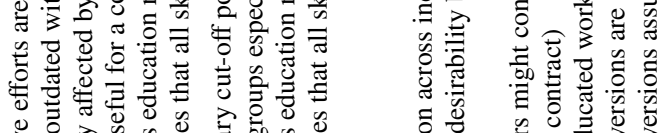

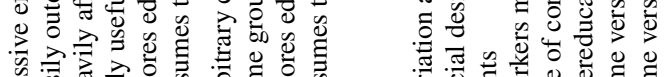

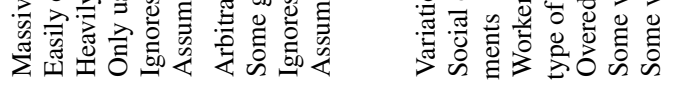

党

1 1 1 1 1 1 1 1

㟝

言

:

苛

:

苞 莺 艼

:

究

总总

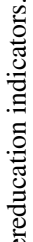

낭

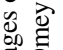

声艺

存

菏

需

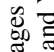

荧

运

究贯

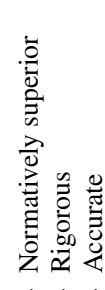

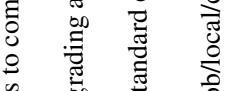

है

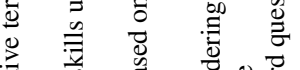

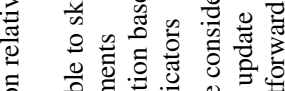

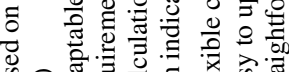

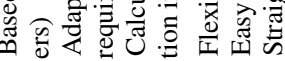

-

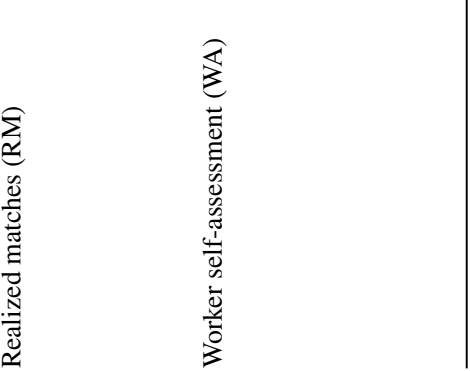


education and occupation contained in most national labour force surveys. However, RM indicators are statistically constructed and it requires that the researcher makes some arbitrary decisions on statistics (e.g. mean, mode) and cut-off points (e.g. one standard deviation) to consider who is and who is not overeducated. Moreover, they are assuming a fairly normal distribution of individuals by years of education within each occupation/job. Using educational levels as a criteria for cut-off points is argued to be less subject to the researcher's arbitrariness and to normal distribution assumptions (Ortiz and Kucel 2008). Similarly to JA indicators, differences in skills and knowledge requirements are not contemplated across jobs in the same occupation. Moreover, they might be heavily affected by credential inflation if employers decide to upgrade qualification requirements but not job tasks. For example, if there are numerous university graduates and a few high-skilled jobs available, restaurants might hire higher educated individuals to work as waiters. According to the RM measurement, university graduates working as waiters are not to be considered as overeducated because the reference point is the rest of the workers in the occupation, instead of the objective requirements to successfully perform the job tasks. Although changes in the supply and/or demand of education and skills are not likely to happen suddenly and heavily affect the population mean, this type of indicator might be less indicated to assess the overeducation incidence of specific groups affected by credential inflation.

Finally, WA indicators are considered as the most flexible indicators in taking into account job and/or local specificities, as well as changes in the nature of jobs across time. This makes WA less biased and easy to update, and they are usually the best empirical available choice. The main limitation of WA indicators is the fact of exclusively relying on individuals' opinions because not all of them may perceive overeducation with the same scale. The benchmarking of their situation might vary depending on the firm size and/or the structure of the organization, leading to measurement error. Social desirability might bias overeducation estimates upward or downward, as individuals may overstate their education and skills to inflate their status (Verhaest and Omey 2010), creating an upward bias. Conversely, individuals might overestimate their jobs' educational requirements to inflate their working status and, thus, it may result in an underestimation of the phenomenon. As WA indicators are based on survey responses, they might be affected by individuals' selection bias in responding to the survey. It might be argued that overeducated workers are more agitated about their labour situation and eager to report it. Contrary to that, overeducation underestimation can also be caused by non-response biases: overeducated workers might be less likely to respond to work related questions because of apathy. There are also some concerns about individuals confounding overeducation with other working conditions - such as wage or type of contract—and/or job satisfaction when asking directly if they think they are overeducated. Additionally, individuals might consider themselves as overeducated based on unaccomplished expectations: the job they are performing is below their initial expectations when conducting their studies, even if it theoretically/objectively matches their educational level. Nevertheless, indirect questions such as Which qualification do you need to do/get the job are straightforward enough and do not leave room for misinterpretation. Some versions of WA are also sensitive to credential inflation: when asking about the qualification to get the job employers might adjust hiring standards to the characteristics of the supply of workers, but not to job characteristics (Hartog 2000). However, empirical evidence presented by Sicherman's (1991) suggests that in the U.S. the rise in the educational level did not bias this indicator upward.

Given the numerous advantages and drawbacks of each indicator, the question to pose is which criteria researchers should use to choose the most suitable overeducation indicator. Depending on the focus and scope of the research (e.g. focus on workers' expectations, in 
Table 2 Use of overeducation measurement by decade. Source: Author's elaboration, based on 108 results from 78 studies on overeducation from Groot and van den Brink (2000), Kucel (2011) and Quintini (2011)

\begin{tabular}{cllllll}
\hline & $1960 \mathrm{~s}$ & $1970 \mathrm{~s}$ & $1980 \mathrm{~s}$ & $1990 \mathrm{~s}$ & $2000 \mathrm{~s}$ & Total \\
\hline JA & & & & & & \\
$\mathrm{N}$ & 1 & 3 & 0 & 12 & 3 & 19 \\
Rate & 0.5 & 0.33 & 0 & 0.21 & 0.13 & 0.18 \\
$\mathrm{RM}$ & & & & & & \\
$\mathrm{N}$ & 0 & 1 & 5 & 13 & 5 & 24 \\
Rate & 0 & 0.11 & 0.31 & 0.22 & 0.22 & 0.22 \\
WA & & & & & & \\
$\mathrm{N}$ & 1 & 5 & 11 & 33 & 15 & 65 \\
Rate & 0.5 & 0.56 & 0.69 & 0.57 & 0.65 & 0.6 \\
Total & & & & & & \\
N & 2 & 9 & 16 & 58 & 23 & 108 \\
Rate & 1 & 1 & 1 & 1 & 1 & 1 \\
\hline
\end{tabular}

Note: Values in italics highlight the largest overeducation rates

depth case study), one kind of measurement might be more advisable than another. The use of more than one indicator as a robustness check is usually advised, as well as combining objective and subjective indicators to show both employers' and workers' points of view. This differentiation is rooted in the conceptualisation and theories regarding overeducation occurrence, attributing more or less importance to workers and firms on the mismatch solution. ${ }^{3}$ However, different indicators of overeducation can provide complementary and non-excluding information on the overeducation phenomenon.

Halaby (1994) pointed out the importance of WA measures in presenting workers' perspectives. He argues that something similar is done for unemployment: individuals are classified as unemployed when they declare that they are actively looking for a job and willing to work. According to him, this is also subjective because the intensity and effort of looking for work is likely to vary across individuals. From a sociological perspective, it is crucial to explore workers' subjective assessments of their own situation in relation to their expectations, the rest of workers and the labour market in general. The use of subjective indicators might be advisable when comparing different countries, sectors, occupations and fields of expertise, since individuals are likely to be more aware of the real possibilities in their domestic labour market than generic and objective classifications.

However, RM indicators might be more appropriate for case studies in countries not affected by credential inflation. It is an objective way to assess overeducation and can also facilitate comparison across workers' cohorts. JA indicators are very accurate but, as mentioned above, they represent a huge effort in terms of time and resources to be constructed and kept updated. Nevertheless, if such effort has already been done and is still taking place like in the U.S. with the O*NET database, it is advisable to use it because of its accuracy and case singularity.

Regardless of researchers' preferences and indicators' suitability, data availability usually dictates the choice (Hartog 2000; McGuinness 2006; Verhaest and Omey 2006). Table 2 below shows the use of the three board groups of overeducation measurements

\footnotetext{
${ }^{3}$ For an extensive discussion of overeducation theories see Capsada-Munsech (2017), Kucel (2011), McGuinness (2006) and Quintini (2011).
} 


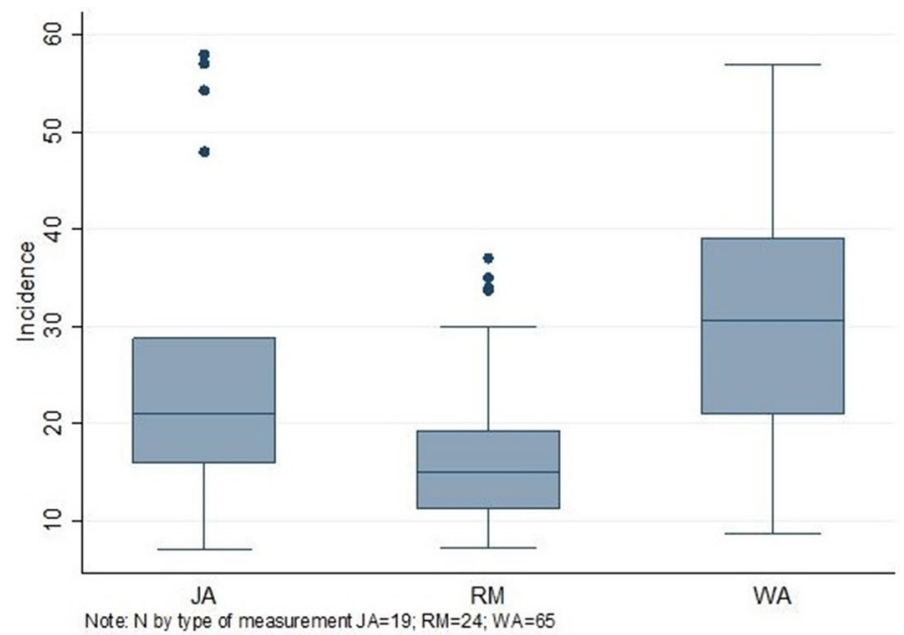

Fig. 2 Distribution of overeducation incidence by type of measurement. Source: Author's elaboration, based on 108 results from 78 studies on over education from Groot and van den Brink (2000), Kucel (2011) and Quintini (2011).

during the past decades. Throughout the years, the use of WA measurements in empirical studies has outpaced the number of studies using objective indicators, becoming more dominant across time. The main reasons are that it is the cheapest and usually the most upto-date measurement available (Hartog 2000).

\section{Empirical Consistency Across Indicators}

Meta-analyses of overeducation incidence across countries show that, on average, objective measurements present lower estimates than subjective ones (Groot and van den Brink 2000; McGuinness 2006; Verhaest and Omey 2006), especially statistical ones (Battu et al. 2000). Based on results from several cross-national and cross-time period studies, Fig. 2 shows that RM indicators present the lowest median overeducation incidence, followed by JA indicators and WA. However, because of the heterogeneity of countries and time periods involved, JA and RM indicators present a few outliers and WA displays accentuated dispersion.

Similarly, Fig. 3 shows the median incidence of overeducation in the Netherlands and the United Kingdom ${ }^{4}$ using the three types of measures considered. In both cases, WA measures show larger figures, while JA and RM present similar median values. In the Netherlands, the RM indicator presents lower dispersion, whereas in the United Kingdom the JA shows more consistent results. Even if the number of cases by indicator and country differs, this information supports the argument that different indicators might be more appropriate in one country rather than in another.

Since in general terms objective indicators present lower figures, one would expect that those who are objectively overeducated are also subjectively overeducated. Nevertheless,

\footnotetext{
4 The Netherlands and the United Kingdom are the only two countries presenting at least one empirical study using each type of overeducation measurement.
} 

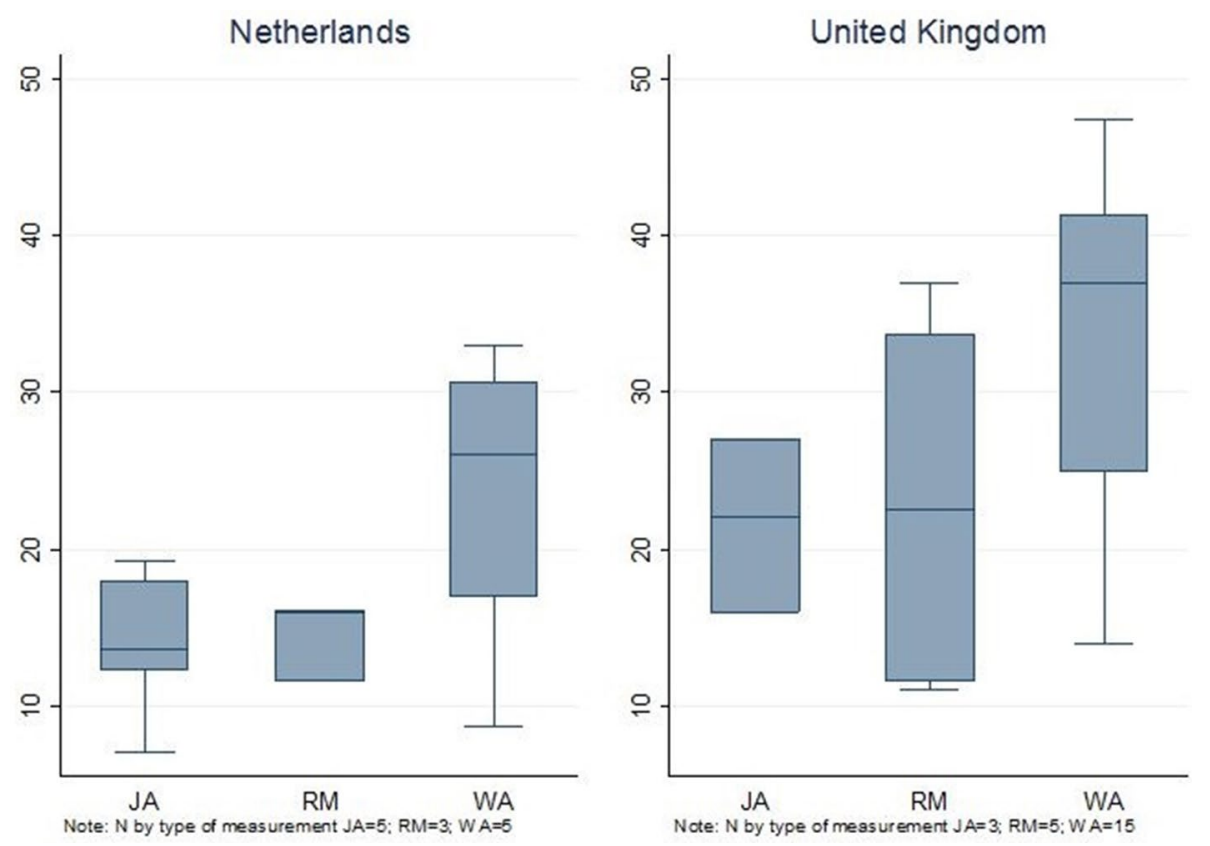

Fig. 3 Overeducation incidence by measurement, The Netherlands and the United Kingdom. Source: Author's elaboration, based on Groot and van den Brink (2000), Kucel (2011) and Quintini (2011)

Table 3 Possible correspondence between two overeducation indicators. Source: Author's elaboration

\begin{tabular}{lll}
\hline & Indicator 1 & Matched \\
\cline { 2 - 3 } & Overeducated & \\
\hline Indicator 2 & & 2. Subjectively overeducation only \\
Overeducated & 1. Consistent (overlap) & 4. Consistent (overlap) \\
Matched & 3. Objectively overeducation only & \\
\hline
\end{tabular}

correlations between objective and subjective indicators are usually low-commonly below 0.50 - and still fairly limited even when comparing two objective indicators (McGuinness 2006). In addition to the correlation, it is also important to check the overlap between indicators in order to address the empirical consistency across measurements and detect the origin of the mismatch. There are four possible situations of (mis)match between two overeducation indicators. Table 3 shows these four possible situations in which individuals might be located. Cells 1 and 4 present robustness between indicators: individuals are considered overeducated or matched by both forms of measurement. Individuals classified in cells 2 and 3 show inconsistent results. Cell 2 includes a group of individuals classified as overeducated by Indicator 2 but not by Indicator 1 . If we consider Indicator 1 as an objective indicator and Indicator 2 as a subjective one, this is not to be considered such a surprising situation. As previously mentioned, overeducation meta-analyses show that subjective indicators tend to present larger figures than objective ones. Cell 3 shows the situation where people are objectively overeducated, but they do not identify themselves 
as subjectively overeducated. This could be considered as the less intuitive and unexpected situation. Some tentative explanations are: (1) the job tasks are more demanding than the formal title/occupation shows; (2) some individuals might have low expectations on job tasks; (3) some individuals might have a limited idea of what a job corresponding to her/ his education is.

This (imperfect) overlap of the indicators has been reported by other scholars, pointing out the difficulty in identifying overeducated individuals according to basic social and demographic factors such as gender (Battu et al. 2000). However, not much attention has been paid to this puzzle. The main reason is that the estimated wage returns to overeducation do not substantially change when using objective or subjective indicators (Battu et al. 2000; McGuinness 2006). The tentative explanation is that different indicators might be picking up different job and personal characteristics relevant to overeducation. However, if overeducation is addressed as a dependent variable, it is important to have a more in depth understanding of the biases and differences across indicators and how they vary within and across countries.

\section{Data and Methods}

With the objective to systematically address the differences in incidence, correlations and overlaps across overeducation measurements, a secondary data analysis using REFLEX/ HEGESCO datasets is employed to provide empirical evidence for higher educated graduates across European countries. REFLEX (Research into Employment and professional FLEXibility) and HEGESCO (Higher Education as a Generator of Strategic Competences) are large-scale European surveys that interview higher educated graduates five years after graduation. They focus on the relationship between higher education, the competences attained by graduates and their use into the labour market. Both present the same set of questions, including information necessary to calculate the different types of overeducation measures mentioned above (i.e. JA, RM, WA). The only difference between the two datasets is the number of countries included and the year the data collection took place. REFLEX provides information on 14 countries $^{5}$ and HEGESCO on 5 additional ones. ${ }^{6}$ However, only 11 European countries ${ }^{7}$ present sufficient information on all the necessary variables to construct the different overeducation indicators considered in the analyses. REFLEX survey includes country representative samples of higher educated graduates who got their degree in the academic year 1999/2000 and surveyed in 2005; HEGESCO data corresponds to graduates from 2002/2003 interviewed in $2008 .{ }^{8}$ In both cases the data collection took place before the effects of the 2008 financial crisis affected the economic and employment situation across Europe. So, results are not expected to be heavily affected by it.

\footnotetext{
5 Austria, Belgium (Flanders), the Czech Republic, Estonia, Finland, France, Germany, Italy, Japan, the Netherlands, Norway, Portugal, Spain and the United Kingdom.

${ }^{6}$ Lithuania, Poland, Hungary, Slovenia and Turkey.

7 France, Estonia, Germany, Japan, Lithuania, Portugal, Turkey and the United Kingdom are not included in the analyses due to the lack of basic information to construct one or more of the indicators considered.

${ }^{8}$ More detailed information on the surveys is available at Allen and van der Velden (2011).
} 
Since REFLEX/HEGESCO only surveys ISCED 5A university graduates ${ }^{9}$ no information on the broader working population is available. Data from the European Union Labour Force Survey (EU-LFS) for the corresponding years-2005 and 2008, country dependent-has been included to calculate the RM indicators, because of the need of a reference point on the mean qualification level within occupations. ISCO information has been used at 1-digit for the calculation of RM and JA indicators. Since no comparable occupational dictionary or any form of standardised job assessment method is available for all the countries considered, the operationalisation of JA indicators has been done comparing broad ISCED and ISCO levels at 1-digit. Although a 2-digit operationalisation would have been preferred to cope with the broad range of jobs within broad occupational groups, samples of graduates employed across 2-digit occupations and countries are too low in a relevant number of cases to provide robust results. The use of REFLEX/HEGESCO instead of the single use of EU-LFS is preferred for the purpose of this article, because of the availability of a WA indicator in REFLEX/HEGESCO, which is inexistent in EU-LFS as pointed out in recently published studies (McGuinness et al. 2018, p. 4).

Five indicators have been constructed taking into account individuals' first relevant job $^{10}$ after graduation:

1. JAl indicator only considering as adequately matched graduates employed in managerial and professional occupations (ISCO 1-2) and as overeducated graduates employed in ISCO 3-9 occupations;

2. JA2 indicator considering as adequately matched graduates employed in managerial, professional and technicians and associate occupations (ISCO 1-3) and as overeducated graduates employed in ISCO 4-9 occupations. The only difference with JA1 is that JA2 considers ISCO 3 occupations as graduate jobs;

3. RM1 indicator considering as overeducated those graduates employed in an occupation (ISCO 1-digit) in which $80 \%{ }^{11}$ of the workers' highest educational level is below ISCED 5A, following Ortiz and Kucel (2008) relative measurement. REFLEX/HEGESCO only interviews graduates who attained ISCED 5A. In order to establish the threshold-educational level of $80 \%$ of workers employed in an occupation-corresponding data by country and year from the EU-LFS has been matched;

4. RM2 indicator considering as overeducated those graduates employed in an occupation (ISCO 1-digit) in which $80 \%$ of the workers' highest educational level is below ISCED 5, following Ortiz and Kucel (2008) relative measurement. REFLEX/HEGESCO only interview graduates who attained ISCED 5A. In order to establish the threshold-educational level of $80 \%$ of workers employed in an occupation-corresponding data by

\footnotetext{
${ }^{9}$ In the ISCED 1997 ISCED 5A programmes are largely theory-based and are designed to provide sufficient qualifications for entry to advanced research programmes and professions with high skill requirements. Tertiary-type A programmes have a minimum cumulative theoretical duration (at tertiary level) of three years' full-time equivalent, although they typically last four or more years. These programmes are not exclusively offered at universities.

${ }^{10}$ Relevant job after graduation is considered if it lasts more than 6 months, including self-employment and trainee jobs.

11 Following Ortiz and Kucel (2008) measurement proposal, robustness checks using a threshold of $70 \%$ of workers' highest educatonal level in an occupation were conducted, which showed no substantial differences in the results discussed in this article. This exercise was replicated for RM1 and RM2 indicators.
} 
Table 4 Overeducation incidence by measurement type. Source: Author's elaboration, using REFLEX/HEGESCO and EU-LFS

\begin{tabular}{|c|c|c|c|c|c|c|}
\hline & \multicolumn{2}{|c|}{ Overeducated } & \multicolumn{2}{|c|}{ Matched } & \multicolumn{2}{|l|}{ Total } \\
\hline & $\mathrm{N}$ & Rate & $\mathrm{N}$ & Rate & $\mathrm{N}$ & Rate \\
\hline JA1 & 10,311 & 0.38 & 16,628 & 0.62 & 26,939 & 1.0 \\
\hline JA2 & 3129 & 0.12 & 23,810 & 0.88 & 26,939 & 1.0 \\
\hline RM1 & 7938 & 0.29 & 19,001 & 0.71 & 26,939 & 1.0 \\
\hline RM2 & 5072 & 0.19 & 21,867 & 0.79 & 26,939 & 1.0 \\
\hline WA & 7384 & 0.29 & 17,738 & 0.71 & 25,125 & 1.0 \\
\hline
\end{tabular}

Note: Values in italics highlight the largest overeducation rates

country and year from the EU-LFS has been matched. The only difference with indicator $\mathrm{RM} 1$ is that RM2 considers typical ISCED $5 \mathrm{~B}^{12}$ as graduate jobs;

5. WA indicator based on the indirect question What type of education do you feel was most appropriate for your first work after graduation? included in REFLEX/HEGESCO surveys. Individuals are considered to be overeducated when the educational level they deem appropriate for the job is below their educational level (ISCED 5A or above). It refers to the education required to perform the job, instead of getting the job.

These five overeducation indicators have been calculated for the 11 European countries considered. In the following section the overeducation incidence reported by each indicator is compared within and across countries, as well as the correlation between different overeducation measurements and the overlaps in identifying overeducated individuals. Finally, the different indicators are used as dependent variables and two relevant predictors of graduates' overeducation (i.e. field of study and parental education) are used to show the different association of individuals' characteristics across measurements, based on the odds ratios reported by logistic regression with country-fixed effects and relevant individuallevel controls.

\section{Results and Discussion}

\subsection{Overeducation Incidence Across Measurements}

Table 4 below shows the variation in overeducation incidence depending on the indicator used. Overall, JA1 considers the highest rate of overeducated graduates (0.38), JA2 the lowest (0.12), followed by RM2 (0.19); RM1 and WA present equivalent rates (0.29). Contrary to previous academic findings, objective indicators do not always present lower rates compared to subjective ones: JA1 presents a larger rate and RM1 the same one. Only RM2 shows a lower rate, compared to WA. Thus, the threshold established in job requirements to consider graduates as overeducated is crucial in this regard. Notwithstanding this variation, cross-measurement differences are smaller than the ones presented by previous

\footnotetext{
12 In the ISCED 1997 ISCED 5B programmes are typically shorter than those of tertiary-type A and focus on practical, technical or occupational skills for direct entry into the labour market, although some theoretical foundations may be covered in the respective programmes. They have a minimum duration of two years full-time equivalent at the tertiary level.
} 

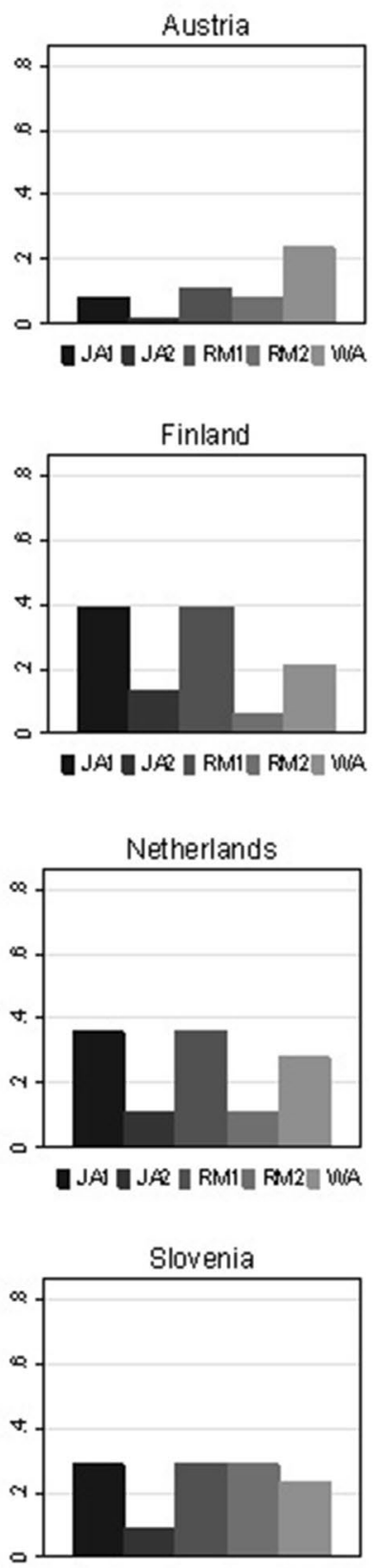

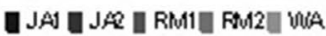
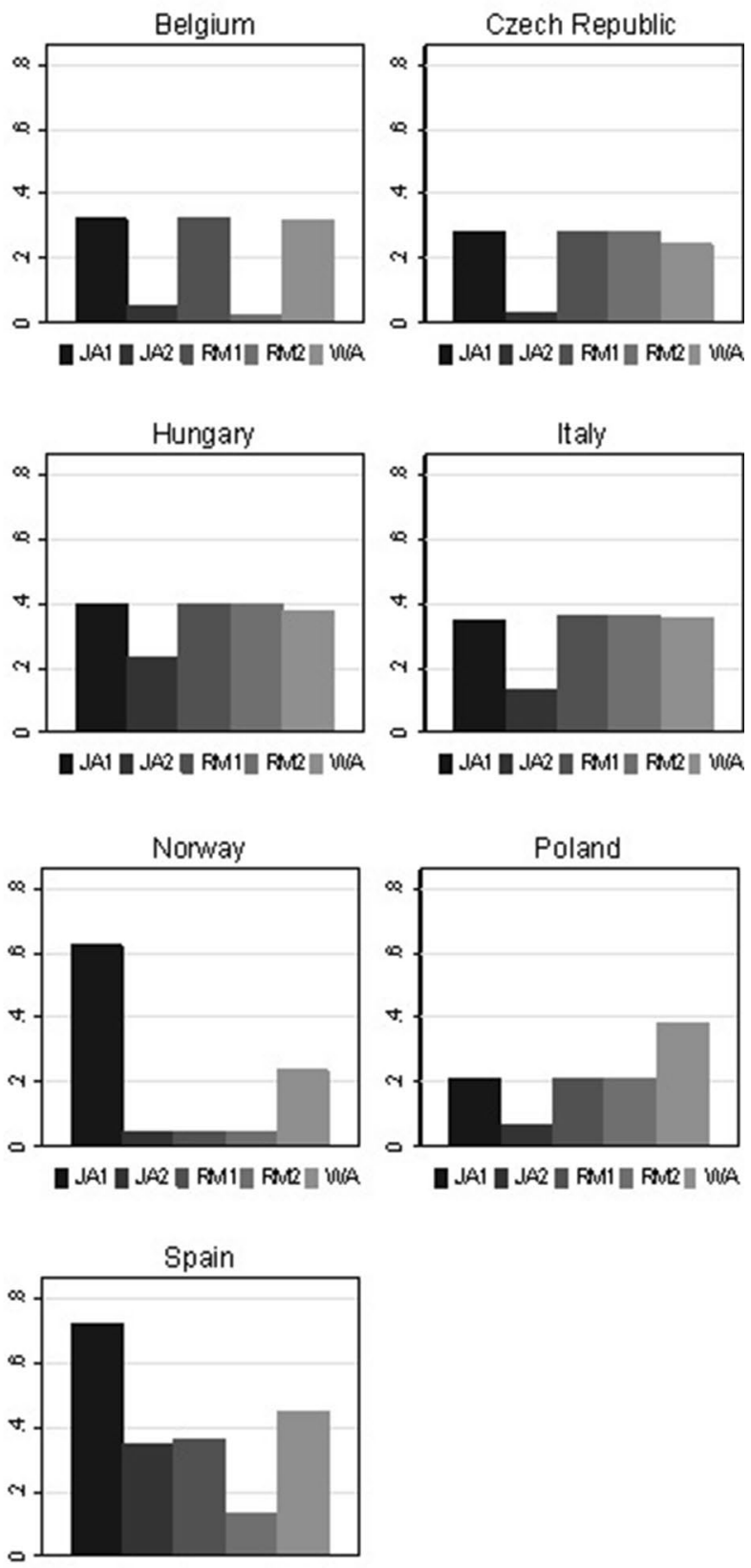

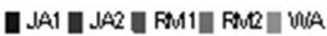

Fig. 4 Overeducation rate by measurement type and country. Source: Author's elaboration, using REFLEX/ HEGESCO and EU-LFS

studies, most of them considering the whole working population. One of the main explanations might be a higher degree of homogeneity provided by the sample of university graduates. However, given the weaknesses in constructing the objective indicators, these results 
should be taken with caution, as the broad classification at ISCO-1 digit gathers a lot of heterogeneity in the entry requirements to the occupations included, being this issue probably more relevant in some countries than others.

Cross-indicator differences also vary across countries. Figure 4 below presents overeducation rates by measurement type and country. Overall, the WA indicator is the one presenting the most consistent rates across countries. Austria and Poland are the only countries where the highest overeducation rate is presented by this subjective indicator. In the rest of the countries, the WA rate is close to the average for the rest of the measurements. Therefore, it seems that WA indicators are useful for cross-country comparisons, at least for the database used. However, caution in the interpretation of resutls is advised, especially in countries where there are a lot of differences across indicators (e.g. Belgium, Finland, the Netherlands, and Spain).

Contrary to WA results, JA and RM indicators largely differ from one country to another, as well as their deviance from the average measurement value within the country. In most countries, there is a large difference between JA1 and JA2 overeducation rate. The only difference between these two indicators is that one considers ISCO 3 occupations as graduate jobs (JA2) and the other does not (JA1). In Norway and Spain, JA1 rates are quite large compared to the rest of the indicators, suggesting that JA2 is a more suitable indicator to be used at the country level because ISCO 3 occupations could be treated as graduate jobs in these countries. Therefore, the JA1 indicator could be considered as an outlier/ biased indicator in Norway and Spain. Conversely, in the rest of the countries JA1 seems to be a better indicator than JA2, meaning that ISCO 3 occupations are not to be considered as graduate jobs. Belgium, Finland and the Netherlands show less conclusive results because of the large differences across objective indicators in general.

With regard to statistical measurements, countries can be grouped into two subsets: those that present the same rate for RM1 and RM2 and those that present a lower RM2 rate compared to RM1. The Czech Republic, Hungary, Italy, Poland and Slovenia present the same RM1 and RM2 rates because in these countries no typical ISCED 5B occupations have been detected, mainly because this type of programme is inexistent or atypical. In the rest of countries, differences between RM1 and RM2 show the rate of what could be considered as a moderate type of overeducation: ISCED 5A graduates employed in typical ISCED 5B occupations. Belgium, Finland, the Netherlands and Spain are the countries presenting a larger difference between RM1 and RM2 and, thus, a higher percentage of moderate overeducation.

\subsection{Correlation Between Overeducation Indicators}

In line with previous research (McGuinness 2006; Verhaest and Omey 2006), results suggest that the correlations across overeducation measurements are not always as high as expected. Table 5 shows that correlations are fairly high between objective indicators, but they are lower between objective and subjective ones. These results are consistent across countries, with Norway and Spain being the exceptions. However, the strength of the relationship varies across countries. In most countries, the correlation between JA1 and RM1 is very high or even perfect, which means that they are identifying the same individuals (i.e. Belgium, Finland, and the Netherlands). In some cases, the correlation is also very high or even 1.0 between JA1 and RM2. This happens in countries that have been identified as lacking typical ISCED 5B occupations (e.g. the Czech Republic, Hungary, Italy, Poland and Slovenia). 
Table 5 Pearson's correlation between overeducation indicators by country. Source: Author's elaboration, using REFLEX/ HEGESCO and EU-LFS

\begin{tabular}{llllll}
\hline \multicolumn{2}{l}{ Overall $(\mathrm{N}=26,939)$} & & & & \\
\hline & JA1 & JA2 & RM1 & RM2 & WA \\
\hline JA1 & 1.0 & - & - & - & - \\
JA2 & 0.46 & 1.0 & - & - & - \\
RM1 & 0.795 & 0.561 & 1.0 & - & - \\
RM2 & 0.603 & 0.472 & 0.745 & 1.0 & - \\
WA & 0.315 & 0.367 & 0.354 & 0.31 & 1.0
\end{tabular}

Austria $(\mathrm{N}=1712)$

$\begin{array}{llllll}\text { JA1 } & 1.0 & - & - & - & - \\ \text { JA2 } & 0.457 & 1.0 & - & - & - \\ \text { RM1 } & 0.847 & 0.387 & 1.0 & - & - \\ \text { RM2 } & 1.0 & 0.457 & 0.847 & 1.0 & - \\ \text { WA } & 0.251 & 0.233 & 0.219 & 0.25 & 1.0\end{array}$

Belgium ( $\mathrm{N}=1265)$

$\begin{array}{llllll}\text { JA1 } & 1.0 & - & - & - & - \\ \text { JA2 } & 0.341 & 1.0 & - & - & - \\ \text { RM1 } & 1.0 & 0.341 & 1.0 & - & - \\ \text { RM2 } & 0.222 & 0.653 & 0.222 & 1.0 & - \\ \text { WA } & 0.328 & 0.238 & 0.328 & 0.16 & 1.0\end{array}$

Czech Republic $(\mathrm{N}=5353)$

$\begin{array}{llllll}\text { JA1 } & 1.0 & - & - & - & - \\ \text { JA2 } & 0.294 & 1.0 & - & - & - \\ \text { RM1 } & 1.0 & 0.294 & 1.0 & - & - \\ \text { RM2 } & 1.0 & 0.294 & 1.0 & 1.0 & - \\ \text { WA } & 0.388 & 0.24 & 0.388 & 0.388 & 1.0\end{array}$

Finland $(\mathrm{N}=2508)$

$\begin{array}{llllll}\text { JA1 } & 1.0 & - & - & - & - \\ \text { JA2 } & 0.487 & 1.0 & - & - & - \\ \text { RM1 } & 1.0 & 0.487 & 1.0 & - & - \\ \text { RM2 } & 0.323 & 0.663 & 0.323 & 1.0 & - \\ \text { WA } & 0.358 & 0.426 & 0.358 & 0.332 & 1.0\end{array}$

Hungary $(\mathrm{N}=1119)$

$\begin{array}{llllll}\text { JA1 } & 1.0 & - & - & - & - \\ \text { JA2 } & 0.675 & 1.0 & - & - & - \\ \text { RM1 } & 1.0 & 0.675 & 1.0 & - & - \\ \text { RM2 } & 1.0 & 0.675 & 1.0 & 1.0 & - \\ \text { WA } & 0.4 & 0.356 & 0.4 & 0.4 & 1.0\end{array}$

Italy $(\mathrm{N}=2673)$

$\begin{array}{llllll}\text { JA1 } & 1.0 & - & - & - & - \\ \text { JA2 } & 0.543 & 1.0 & - & - & - \\ \text { RM1 } & 0.966 & 0.525 & 1.0 & - & - \\ \text { RM2 } & 0.966 & 0.525 & 1.0 & 1.0 & - \\ \text { WA } & 0.356 & 0.326 & 0.364 & 0.364 & 1.0\end{array}$

Netherlands $(\mathrm{N}=3262)$

$\begin{array}{lll}\text { JA1 } & 1.0 & - \\ \text { JA2 } & 0.466 & 1.0\end{array}$


Table 5 (continued)

\begin{tabular}{lcllll}
\hline \multicolumn{2}{l}{ Overall $(\mathrm{N}=26,939)$} & & & & \\
\hline & JA1 & JA2 & RM1 & RM2 & WA \\
\hline RM1 & 1.0 & 0.466 & 1.0 & - & - \\
RM2 & 0.466 & 1.0 & 0.466 & 1.0 & - \\
WA & 0.205 & 0.253 & 0.205 & 0.253 & 1.0 \\
Norway $(\mathrm{N}=2126)$ & & & & \\
JA1 & 1.0 & - & - & - & - \\
JA2 & 0.164 & 1.0 & - & - & - \\
RM1 & 0.164 & 1.0 & 1.0 & - & - \\
RM2 & 0.164 & 1.0 & 1.0 & 1.0 & - \\
WA & -0.024 & 0.347 & 0.347 & 0.347 & 1.0
\end{tabular}

Poland $(\mathrm{N}=590)$

$\begin{array}{llllll}\text { JA1 } & 1.0 & - & - & - & - \\ \text { JA2 } & 0.512 & 1.0 & - & - & - \\ \text { RM1 } & 1.0 & 0.512 & 1.0 & - & - \\ \text { RM2 } & 1.0 & 0.512 & 1.0 & 1.0 & - \\ \text { WA } & 0.253 & 0.194 & 0.253 & 0.253 & 1.0\end{array}$

Slovenia $(\mathrm{N}=2555)$

$\begin{array}{llllll}\text { JA1 } & 1.0 & - & - & - & - \\ \text { JA2 } & 0.482 & 1.0 & - & - & - \\ \text { RM1 } & 1.0 & 0.482 & 1.0 & - & - \\ \text { RM2 } & 1.0 & 0.482 & 1.0 & 1.0 & - \\ \text { WA } & 0.28 & 0.265 & 0.28 & 0.28 & 1.0\end{array}$

Spain $(\mathrm{N}=3432)$

$\begin{array}{llllll}\text { JA1 } & 1.0 & - & - & - & - \\ \text { JA2 } & 0.45 & 1.0 & - & - & - \\ \text { RM1 } & 0.382 & 0.96 & 1.0 & - & - \\ \text { RM2 } & 0.239 & 0.532 & 0.512 & 1.0 & - \\ \text { WA } & 0.399 & 0.554 & 0.54 & 0.377 & 1.0\end{array}$

Note: Values in italics highlight the larger overeducation rates in each country

Table 6 Correspondence between self-reported and normative indicators. Source: author's elaboration, using REFLEX/HEGESCO

\begin{tabular}{llrlrr}
\hline & \multicolumn{1}{l}{ JA1 } & & \multicolumn{2}{l}{ JA2 } & \\
\cline { 2 - 3 } \cline { 5 - 6 } & Overeducated & Matched & & Overeducated & Matched \\
\hline WA & & & & \\
Overeducated & $4555(18.52 \%)$ & $2634(10.71 \%)$ & & $2222(9.04 \%)$ & $4967(20.20 \%)$ \\
Matched & $5131(20.87 \%)$ & $12,271(49.90 \%)$ & & $782(3.18 \%)$ & $16,620(67.59 \%)$ \\
\hline
\end{tabular}

Note: Values in italics show the mismatches between indicators 
Table 7 Correspondence between self-reported and statistical indicators. Source: Author's elaboration, from REFLEX/HEGESCO and EU-LFS

\begin{tabular}{llllll}
\hline & \multicolumn{2}{l}{ RM1 } & & \multicolumn{2}{l}{ RM2 } \\
\cline { 2 - 3 } \cline { 5 - 6 } & Overeducated & Matched & & Overeducated & Matched \\
\hline WA & & & & \\
Overeducated & $4014(16.32 \%)$ & $3175(12.91 \%)$ & & $2742(11.15 \%)$ & $4447(18.08 \%)$ \\
Matched & $3484(14.17 \%)$ & $13,918(56.60 \%)$ & & $1967(8.00 \%)$ & $15,435(62.77 \%)$ \\
\hline
\end{tabular}

Note: Values in italics show the mismatches between indicators

Table 8 Correspondence between normative and statistical indicators. Source: Author's elaboration, using REFLEX/HEGESCO and EU-LFS

\begin{tabular}{llrlrr}
\hline 0 & \multicolumn{2}{l}{ RM1 } & & \multicolumn{2}{l}{ RM2 } \\
\cline { 2 - 3 } \cline { 5 - 6 } & Overeducated & Matched & & Overeducated & Matched \\
\hline JA1 & & & & \\
Overeducated & $7782(28.89 \%)$ & $2529(9.39 \%)$ & & $5030(18.67 \%)$ & $5281(19.60 \%)$ \\
Matched & $156(0.58 \%)$ & $16,472(61.15 \%)$ & & $42(0.16 \%)$ & $16,586(61.57 \%)$ \\
JA2 & $3129(11.62 \%)$ & $0(0.0 \%)$ & & $2180(8.09 \%)$ & $949(3.52 \%)$ \\
Overeducated & $4809(17.85 \%)$ & $19,001(70.53 \%)$ & $2892(8.09 \%)$ & $20,918(77.65 \%)$ \\
Matched & & & & \\
\hline
\end{tabular}

Note: Values in italics show the mismatches between indicators

Across all countries-except Norway and Spain - the correlation between objective indicators (JA and RM) is higher than between any objective and subjective ones (WA). This finding is in line with the idea that objective and subjective indicators are tackling different dimensions of overeducation. While objective indicators focus on job conditions and employers' views, subjective indicators are capturing employees' perspectives on their education suitability and/or need for their job.

\subsection{Overlap Across Overeducation Indicators}

Tables 6, 7 and 8 below reproduce the exercise proposed in Table 3 presenting the four possible (mis)matches/overlaps between two overeducation indicators using REFLEX/ HEGESCO data. Similarly to the correlation coefficients, the largest overlap on overeducation incidence is between JA1-RM1 (28.89\%), with the overlap between WA-JA1 (18.52\%) and WA-RM1 (16.32\%) being much smaller. However, it is interesting to check cells 2 (overeducated in subjective terms, but not in objective ones) and 3 (subjectively matched, but objectively overeducated) in Tables 6 and 7. The correspondence between WA-JA2 and WA-RM2 works as expected: the percentage of university graduates who self-assess as overeducated but are objectively matched (cell 2) outpaces the share of individuals who are objectively overeducated but do not identify themselves as such (cell 3). Contrary to this, correspondence between WA-JA1 and WA-RM1 shows the opposite results: the share of individuals in cell 3 outpaces the one in cell 2 . This might probably have much to do with 

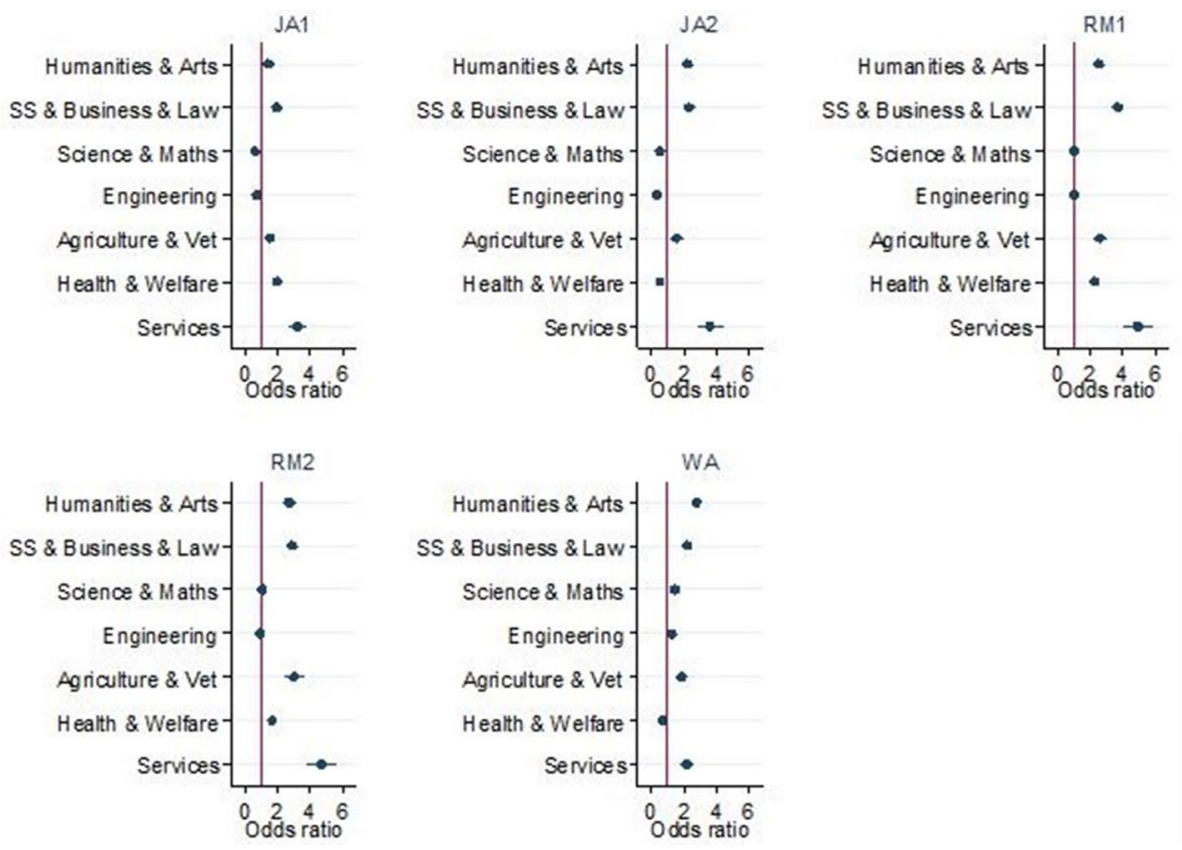

Fig. 5 Odds ratio of being overeducated by field of study and overeducation measurement. Note: odds-ratio coefficients based on logistic regression with country-fixed effects and individual-level controls for gender, age, immigration background, full-time student and father's education. Reference category: education. Source: Author's elaboration, using REFLEXHEGESCO and EU-LFS

the bias in constructing these indicators, as only ISCO 1 and 2 occupations are considered as graduate jobs, while some jobs included in the ISCO 3 might be considered as matched.

Results between WA-JA1 and WA-RM1 are opposite to what is theoretically expected, as the situation presented in cell 2 (overeducated in subjective terms, but not in objective ones) is considered as more intuitive than the one considered in cell 3 (subjectively matched, but objectively overeducated). Therefore, it could be argued that JA1 and RM1 indicators are upwardly biased, considering as non-graduate occupations some jobs individuals deem to be adequately matched with their educational level. However, it is worth pointing out at this stage that these are overall results and they are likely to vary across countries, as suggested by the differences in incidence and cross-measurement correlations presented above.

\subsection{Overeducation Measurements by Field of Study and Father's Education}

In addition to the empirical inconsistencies across overeducation measurements with regards to their correlation and overlap, different indicators might be picking up individuals with different characteristics. To illustrate it, a basic exploration assessing to what extent overeducation likelihood by field of study and father's education differs across overeducation measurements follows. The selection of these two independent variables is based on previous findings, as field of study (Barone and Ortiz 2011; Mavromaras and McGuinness 


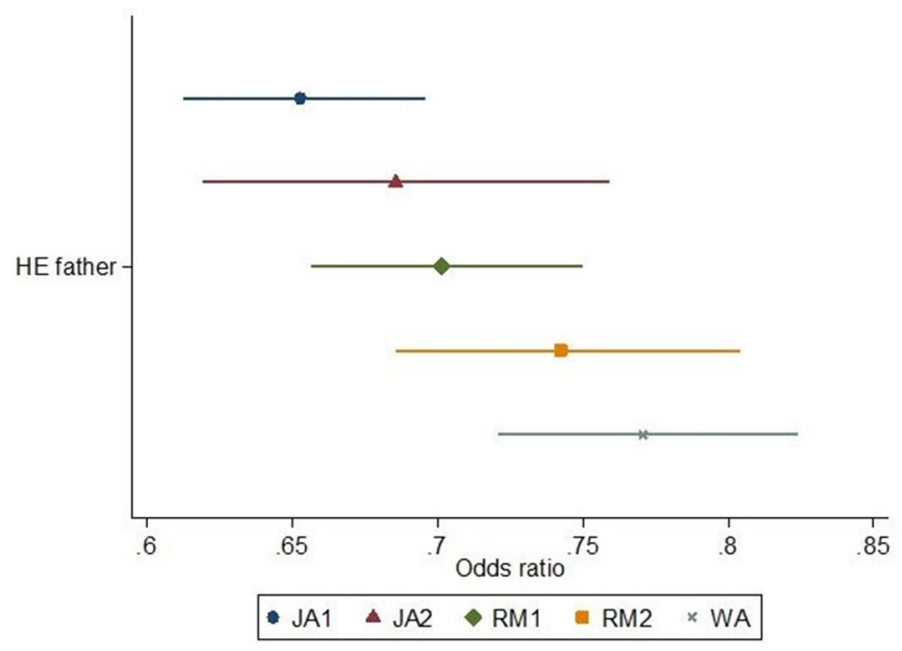

Fig. 6 Odds ratio of being overeducated by father's education and overeducation measurement. Note: oddsratio coefficients based on logistic regression with country-fixed effects and individual-level controls for gender, age, immigration background; full-time student and fields of study. Reference category: non-higher educated father. Source: Author" s elaboration using REFLEX/HEGESCO and EU-LFS

2012; Ortiz and Kucel 2008; Robst 2007) and social origin (Argentin and Triventi 2011; Barone and Ortiz 2011) have been pointed out as relevant predictors of overeducation incidence among higher educated graduates.

Figure 5 below shows the odds ratio to be overeducated by field of study, compared to education graduates. Although results are fairly consistent across indicators, there are some differences worth pointing out. Compared to education graduates, humanities and arts, social sciences, business and law, agriculture and veterinary and services ${ }^{13}$ graduates are more likely to be overeducated, regardless of the measurement used. Nevertheless, the magnitude of the effect varies across overeducation measurements, being RM1 and RM2 the ones presenting larger differences. In the rest of the fields of study considered, the results are not as consistent. Sciences and maths and engineering graduates are similarly likely to be overeducated to education graduates (RM1, RM2), although some indicators point to slightly larger (WA) or lower (JA1, JA2) likelihood of being overeducated. Health and welfare graduates present more contradictory results: they are less likely to be overeducated than education graduates according to some indicators (JA2, WA), but more likely to be overeducated according to others (JA1, RM1, RM2).

The size effect largely differs across measurements. The WA indicator shows limited differences in overeducation likelihood across fields of study, while objective indicators (both normative and statistical) show larger variations in overeducation likelihood across fields of study. Thus, it could be argued that the WA indicator is the most conservative one, according to the way different overeducation measurements have been operationalised.

With regard to the father's education, Fig. 6 shows that all indicators present the same substantive result: the odds of being overeducated are lower for graduates with a higher

\footnotetext{
13 Graduates from studies related to social, personal, safety, security and transport services are included in this category.
} 
educated father, compared to their colleagues whose father is not a university graduate. Nevertheless, it is worth pointing out that the magnitude of the effect varies depending on the indicator used. The JA1 indicator presents the lowest odds ratio compared to the rest of the overeducation indicators. Therefore, this indicator shows the largest difference in overeducation likelihood between offspring of higher educated and non-higher educated. Differences between groups decrease when using JA2, RM1, RM2 and WA, with WA being the one presenting the more limited advantage to avoid overeducation among offspring of higher educated.

\section{Conclusions}

This article aims at discussing the advantages and drawbacks of different overeducation indicators providing evidence with regards to their incidence, correlation and overlap across European countries. Empirical evidence presented suggests that different types of overeducation measurements provide different overeducation rates even for university graduates, which is a group of workers more homogenous than the whole working population. While these results are in line with previous research findings (McGuinness 2006; Verhaest and Omey 2006, 2010), the contribution of the present article is the focus on the use of overeducation measurements in comparative studies.

Results from the comparative analysis show that Worker self-Assessment (WA) measurement is the one providing more consistent and reliable overeducation rates across countries, suggesting that this type of indicators can more easily deal with cross-national differences with regard to job/occupation requirements. The main shortcoming of Job Analysis (JA) and Realized Matches (RM) indicators for comparative purposes is to set a criteria or threshold of what is to be considered as a graduate job in each country, or a common one that makes sense in as many countries as possible. Compared to the rest of the overeducation measurements explored, the WA indicator is the one providing more conservative results with regard to the predictive power of fields of study and father's education on overeducation, two relevant predictors of graduates' overeducation (Barone and Ortiz 2011).

Beyond comparative studies, the results presented suggest that in single country or few countries studies JA and RM indicators are to be considered: JA can be an adequate indicator for countries that have constructed and updated a national job occupation dictionary. RM can be a good choice in countries where jobs rapidly adapt to technological and educational expansion changes, and are not affected by credential inflation.

Therefore, the reflections and results from this article provide evidence that different types of overeducation measurements not only provide different incidence rates, but also identify individuals with different characteristics. Since the correlation and overlap is not the same across indicators, the use of at least two indicators-ideally an objective and a subjective one-is strongly advised in single country studies. In these cases, it should probably become common practice to use at least two overeducation indicators whenever possible and acknowledge the correlation and overlaps between them, in addition to the commonly reported variation in the association between each overeducation indicator and the main predictors under study. This exercise would strengthen the reliability of indicators and point out to the trade-offs and limitations faced by researchers in the operationalisation of overeducation. 
Acknowledgements I am grateful to the two anonymous reviewers for their comments, which helped me improve this article. I would also like to thank Seamus McGuinness and Luis Ortiz for their invaluable comments on previous versions of this article. I am also thankful to Michele Schweisfurth and Patricia Wallace for organising a writing retreat in June 2018 at New Lanark that allowed me to finalise and submit this article.

Open Access This article is distributed under the terms of the Creative Commons Attribution 4.0 International License (http://creativecommons.org/licenses/by/4.0/), which permits unrestricted use, distribution, and reproduction in any medium, provided you give appropriate credit to the original author(s) and the source, provide a link to the Creative Commons license, and indicate if changes were made.

\section{References}

Allen, J., \& van der Velden, R. (2011). The flexible professional in the knowledge society. Berlin: Springer.

Argentin, G., \& Triventi, M. (2011). Social inequality in higher education and labour market in a period of institutional reforms: Italy, 1992-2007. Higher Education, 61(3), 309-323.

Barone, C., \& Ortiz, L. (2011). Overeducation among European University Graduates: A comparative analysis of its incidence and the importance of higher education differentiation. Higher Education, 61(3), 325-337.

Battu, H., Belfield, C. R., \& Sloane, P. J. (2000). How well can we measure graduate over-education and its effects? National Institute Economic Review, 171(1), 82-93.

Bauer, T. K. (2002). Educational mismatch and wages: A panel analysis. Economics of Education Review, 21(3), 221-229.

Burris, V. (1983). The social and political consequences of overeducation. American Sociological Review, 48(4), 454-467.

Capsada-Munsech, Q. (2017). Overeducation: Concept, theories, and empirical evidence. Sociology Compass, 11(10), 1-17. https://doi.org/10.1111/soc4.12518.

Chevalier, A. (2003). Measuring over-education. Economica, 70(279), 509-531.

Clogg, C., \& Shockey, J. W. (1984). Mismatch between occupation and schooling: A prevalence measure, recent trends and demographic analysis. Demography, 21(1), 235-257.

Dolton, P. J., \& Silles, M. (2008). The effects of over-education on earnings in the graduate labour market. Economics of Education Review, 27(2), 125-139.

Duncan, G., \& Hoffman, S. D. (1981). The incidence and wage effects of overeducation. Economics of Education Review, 1(Winter), 75-86.

Eckaus, R. S. (1964). Economic criteria for education and training. The Review of Economics and Statistics, 47(2), 181-190.

Flisi, S., Goglio, V., Meroni, E. C., Rodrigues, M., \& Vera-Toscano, E. (2017). measuring occupational mismatch: Overeducation and overskill in Europe-Evidence from PIAAC. Social Indicators Research, 131(3), 1211-1249. https://doi.org/10.1007/s11205-016-1292-7.

Freeman, R. (1976). The overeducated American. Cambridge: Academic Press.

Groot, W., \& van den Brink, H. M. (1997). Allocation and the returns to over-education in the UK. Education Economics, 5(2), 169-183.

Groot, W., \& van den Brink, H. M. (2000). Overeducation in the labor market: A meta-analysis. Economics of Education Review, 19(2), 149-158.

Halaby, C. N. (1994). Overeducation and skill mismatch. Sociology of Education, 67(1), 47-59.

Hartog, J. (2000). Over-education and earnings: Where are we, where should we go? Economics of Education Review, 19(2), 131-147.

International Labour Organisation. (2008). International standard classification of occupations. Structure, group definitions and correspondence tables. ISCO-08 (Vol. 1). Retrieved from http://www.ilo.org/ public/english/bureau/stat/isco/docs/publication08.pdf. Accessed 8 June 2018.

Kucel, A. (2011). Literature survey of the incidence of over-education: A sociological approach. Revista Española de Investigaciones Sociológicas, I(134), 125-142.

Mateos Romero, L., Murillo Huertas, I. P., \& del Mar Salinas Jiménez, M. (2017). Wage effects of cognitive skills and educational mismatch in Europe. Journal of Policy Modeling, 39(5), 909-927. https://doi. org/10.1016/j.jpolmod.2017.08.001.

Mavromaras, K., \& McGuinness, S. (2012). Overskilling dynamics and education pathways. Economics of Education Review, 31(5), 619-628. 
McGuinness, S. (2006). Overeducation in the labour market. Journal of Economic Surveys, 20(3), 387-418.

McGuinness, S., Bergin, A., \& Whelan, A. (2018). Overeducation in Europe: Trends, convergence, and drivers. Oxford Economic Papers. https://doi.org/10.1093/oep/gpy022.

Mendes de Oliveira, M., Santos, M. C., \& Kiker, B. F. (2000). The role of human capital and technological change in overeducation. Economics of Education Review, 19(2), 199-206.

Ortiz, L., \& Kucel, A. (2008). Do fields of study matter for over-education?: The cases of Spain and Germany. International Journal of Comparative Sociology, 49(4-5), 305-327.

Quintini, G. (2011). Over-qualified or under-skilled? A review of existing literature. OECD social, employment and migration working papers, OECD Publishing (121).

Robst, J. (2007). Education and job match: The relatedness of college major and work. Economics of Education Review, 26(4), 397-407.

Rumberger, R. W. (1981). The rising incidence of overeducation in the U.S. labor market. Economics of Education Review, 1(3), 293-314.

Schofer, E., \& Meyer, J. W. (2005). The worldwide expansion of higher education in the twentieth century. American Sociological Review, 70(6), 898-920.

Scoville, J. G. (1966). Education and training requirements for occupations. The Review of Economics and Statistics, 48(4), 387-394.

Sicherman, N. (1991). “ Overeducation “ in the labor market. Journal of Labour Economics, 9(2), 101-122.

Sloane, P. J., Battu, H., \& Seaman, P. T. (1999). Overeducation, undereducation and the British labour market. Applied Economics, 31(11), 1437-1453.

UNESCO. (2011). Revision of the International Standard Classification of Education (ISCED). General conference 36th session, 36 C/19, 5 September 2011, Paris.

Verdugo, R. R., \& Verdugo, N. T. (1989). The impact of surplus schooling on productivity and earnings. The Journal of Human Resources, 24(4), 629. https://doi.org/10.2307/145865.

Verhaest, D., \& Omey, E. (2006). The impact of overeducation and its measurement. Social Indicators Research, 77, 419-448.

Verhaest, D., \& Omey, E. (2010). The determinants of overeducation: Different measures, different outcomes? International Journal of Manpower, 31(6), 608-625.

Verhaest, D., \& van der Velden, R. (2013). Cross-country differences in graduate overeducation. European Sociological Review, 29(3), 642-653.

Publisher's Note Springer Nature remains neutral with regard to jurisdictional claims in published maps and institutional affiliations. 